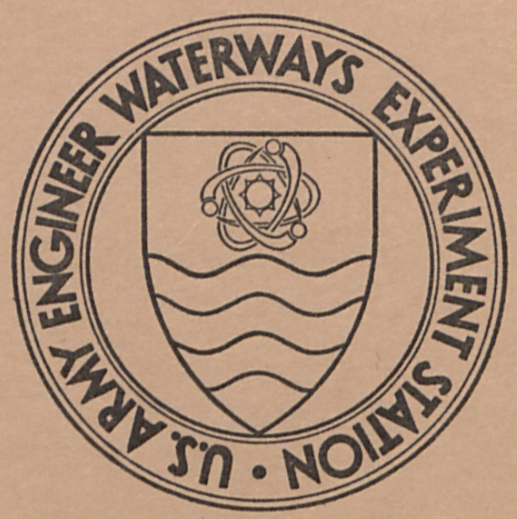

MISCELLANEOUS PAPER S-73-3

\title{
VIBROSEISMIC SURVEY, HIGH REYNOLDS NUMBER TUNNEL SITE, ARNOLD \\ ENGINEERING DEVELOPMENT CENTER
ARNOLD AIR FORCE STATION, TENNESSEE \\ ENGINEERING DEVELOPMENT CENTER
ARNOLD AIR FORCE STATION, TENNESSEE by
}

J. Fowler
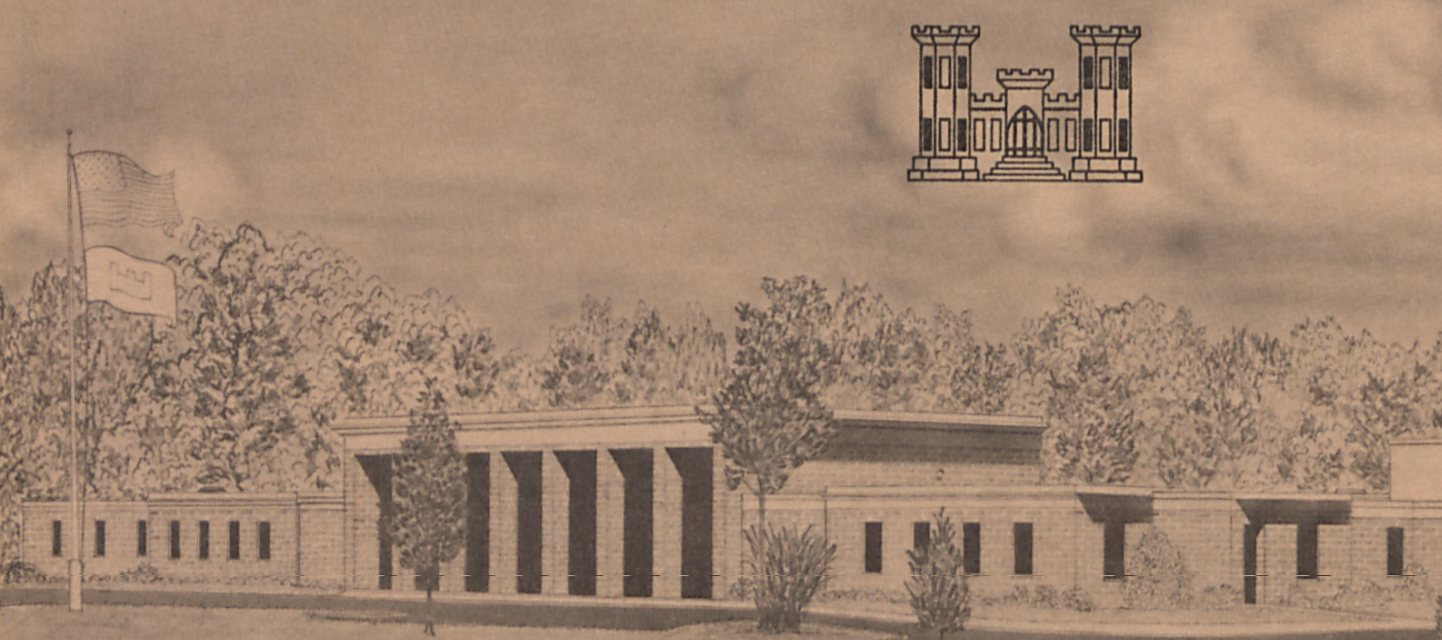

February 1973

Conducted by U. S. Army Engineer Waterways Experiment Station

Soils and Pavements Laboratory

Vicksburg, Mississippi 


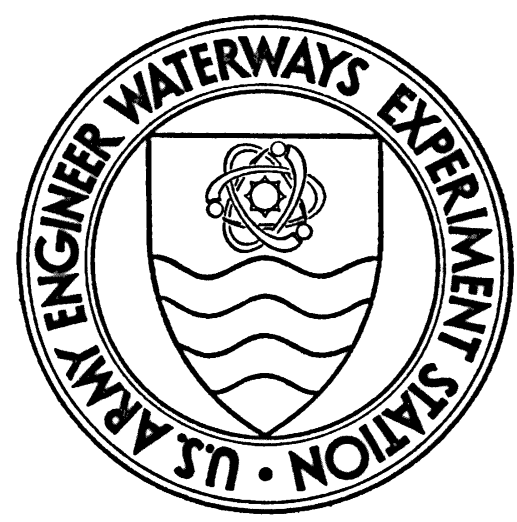

MISCELLANEOUS PAPER S-73-3

\section{VIBROSEISMIC SURVEY, HIGH REYNOLDS NUMBER TUNNEL SITE, ARNOLD ENGINEERING DEVELOPMENT CENTER ARNOLD AIR FORCE STATION, TENNESSEE by \\ J. Fowler}

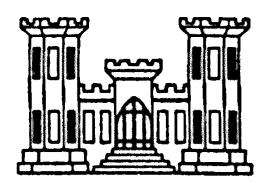

February 1973

Conducted by U. S. Army Engineer Waterways Experiment Station Soils and Pavements Laboratory Vicksburg, Mississippi 


\section{FOREWORD}

The investigation reported herein was authorized by the Arnold Engineering Development Center (AEDC) in a letter dated 26 September 1972, subject, "Vibroseismic Surveys, High Reynolds Number Tunnel (HIRT), AEDC." This letter requested that a conventional vibroseismic survey be conducted at the location of the planned HIRT facility.

This report presents the results of the vibroseismic survey, which was performed during the period of 8-17 November 1972. Engineers actively engaged in the fleld investigation and analysis and report phases of this survey were Messrs. R. W. Cunny, R. F. Ballard, Jr., and J. Fowler of the Solls and Pavements Laboratory, and Mr. T. I. McGill, Jr., of the Instrumentation Branch, Technical Services Division. This work was conducted under the general supervision of Messrs. J. P. Sale, Chief, and R. G. Ahlvin, Assistant Chief, Solls and Pavements Laboratory. The report was prepared by Mr. Fowler.

COL Ernest D. Peixotto, CE, was Director of the WES during the conduct of the investigation and preparation of this report, and Mr. F. R. Brown was Technical Director.

Acknowledgment is made to the Director of Civil Engineering and United States Alr Force personnel of the AEDC for their assistance and cooperation in the performance of this investigation. 
CONTENTS

$\underline{\text { Page }}$

FOREWORD . . . . . . . . . . . . . . . . . . . . ili

SUMMARY . . . . . . . . . . . . . . . . . . . . vii

PART I: INTRODUCTION . . . . . . . . . . . . . . . 1

Background .. . . . . . . . . . . . . . . . 1

Purpose and Scope ... . . . . . . . . . . . . . 1

PART II: THE INVESTIGATION..$\cdot$. . . . . . . . . . . 2

Location, Description, and Soil Conditions of Test Site $\cdot 2$

Test Methods and Computations . . . . . . . . . . 3

PART III: TESTS CONDUCTED AND ANALYSIS AND DISCUSSION

OF RESULTS . . . . . . . . . . . . . . 7

Refraction Seismic Tests . . . . . . . . . . 7

Vibration Tests . . . . . . . . . . . . . . 7

PART IV: CONCLUSIONS •. . . . . . . . . . . . . . . 9

TABLE 1

PLATES $1-11$ 


\section{SUMMARY}

The results of the vibroseismic survey at the proposed HIRT site indicated that three subsurface zones existed. The near-surface zone ranged in compression-wave velocity from 2170 to $2500 \mathrm{fps}$ (660 to 760 $\mathrm{m} / \mathrm{s}$ ) to a maximum depth of $10.7 \mathrm{ft}(3.3 \mathrm{~m})$. The second zone exhibited velocities from 2950 to $5130 \mathrm{fps}(900$ to $1560 \mathrm{~m} / \mathrm{s})$ to a depth of 48 to $92 \mathrm{ft}$ ( 15 to $28 \mathrm{~m}$ ). Below this zone limestone bedrock was encountered that ranged in velocity from 14,300 to 21,000 fps $(4360$ to $6400 \mathrm{~m} / \mathrm{s})$. Shear-wave velocities varied from $700 \mathrm{fps}(215 \mathrm{~m} / \mathrm{s})$ at $11.2 \mathrm{ft}$ $(3.4 \mathrm{~m})$ to $1000 \mathrm{fps}(305 \mathrm{~m} / \mathrm{s})$ at $40.0 \mathrm{ft}(12.2 \mathrm{~m})$. The shear moduli ranged from 10,000 to $20,000 \mathrm{psi}\left(705\right.$ to $1410 \mathrm{~kg} / \mathrm{cm}^{2}$ ) at 11.2 and 40.0 ft $(3.4$ and $12.2 \mathrm{~m})$, respectively. Compression moduli were about three times the shear moduli for corresponding depths. Poisson's ratios genera1ly ranged from 0.45 to 0.47 . Shear and compression moduli generally increased with depth. 


\section{VIBROSEISMIC SURVEY \\ HIGH REYNOLDS NUMBER TUNNEL SITE \\ ARNOLD ENGINEERING DEVELOPMENT CENTER \\ ARNOLD AIR FORCE STATION, TENNESSEE}

\section{PART I: INTRODUCTION}

\section{$\underline{\text { Background }}$}

1. This investigation describes and gives the results of a vibroseismic survey performed at the proposed site for the High Reynolds Number Tunnel (HIRT), which is to be constructed at the Arnold Engineering Development Center (AEDC), Arnold Air Force Station, Tennessee. The facility is to be used to provide a full-scale flight Reynolds number for transonic flow in which meaningful aerodynamic tests can be made on future flight vehicles. The facility will be used to provide Reynolds numbers 15 times those obtainable from present wind tunnels.

\section{Purpose and Scope}

2. The field investigation was conducted for the purpose of determining the dynamic characteristics of the subsurface materials to be used in the foundation design for the HIRT facility. Specifically, these tests were conducted to determine the shear and compression moduli and Poisson's ratios of the foundation materials. 
PART II: THE INVESTIGATION

Location, Description, and Soil Conditions of Test Site

3. The site investigated is at the AEDC, which is located approximately 70 miles $(113 \mathrm{~km})$ SSE of Nashville, Tenn., and approximately 70 miles $(113 \mathrm{~km})$ WNW of Chattanooga, Tenn. The site is located north of 1st Street along a temporary road that is an extension of Avenue "C." Plate 1 is a general site map of the AEDC showing the proposed location for the wind tunnel, the temporary road extending from Avenue " $C$," and the general location of adjacent buflding areas and roadways. The project and operations building and the major components of the wind tunnel are located about 3200 to $3400 \mathrm{ft}$ (975 to $1035 \mathrm{~m}$ ) north of 1st Street (plate 2). The general configuration of the HIRT showing a profile view and approximate dimensions is shown in plate 3 . The wind tunnel is about $12.8 \mathrm{ft}(3.9 \mathrm{~m})$ in diameter and over $1800 \mathrm{ft}(549 \mathrm{~m})$ long.

4. The proposed HIRT site is located in an area that is relatively flat except for slight variations in elevation. A drainage ditch, approximately $6 \mathrm{ft}(1.8 \mathrm{~m})$ deep and $12 \mathrm{ft}(3.7 \mathrm{~m})$ wide, crosses the site at a distance of about $2300 \mathrm{ft}(700 \mathrm{~m})$ north of 1 st Street. The terrain is covered with medium-size trees and underbrush. The water table was found to be about $1 \mathrm{ft}(0.3 \mathrm{~m})$ deep and water was standing in low areas at various locations on the site. Four-foot-deep $(1.2 \mathrm{~m})$, hand-augered holes dug for the, explosives during the seismic tests indicated that the surface materials were very weak, and the holes filled very rapidly with water.

5. A soll exploration program was conducted by the Mobile District, Corps of Engineers, with borings at various locations in the vicinity of the proposed facility. One boring was placed about $300 \mathrm{ft}(90 \mathrm{~m})$ north of the north end of the tunnel, but most of the borings were located from 1500 to $2500 \mathrm{ft}(460$ to $760 \mathrm{~m})$ from the facility. An inftial investigation described in "Project Development Booklet for the 390-128 Transonic 
Aerodynamic Wind Tunnel (High Reynolds Number Tunnel (HIRT))," September 1972, showed that the soll data obtained from this area tentatively indicated that there are no unusual soil conditions that would adversely affect estimated foundation costs.

6. Previous soil borings indicated that the depth to top of rock varies from approximately 50 to $90 \mathrm{ft}(15$ to $27 \mathrm{~m})$ below the surface at AEDC. The bedrock varies from gray to light gray limestone. The surface soils are considered to be residual and consist of about 3 to 6 in. $(7.6$ to $15.2 \mathrm{~cm}$ ) of dark organic top soil over a lean clay varying in thickness from about 3 to $12 \mathrm{ft}(0.9$ to $3.7 \mathrm{~m})$, which is underlain by harder layers of red silty sand and clays from about 10 to $16 \mathrm{ft}$ (3.0 to $4.9 \mathrm{~m}$ ) and layers of brown and yellow silt and tan silty sand down to the top of the limestone. These materials contain gravel and rock fragments that hampered drilling operations. Some cavities were encountered in the limestone during the drilling operation.

7. Mobility along the temporary road to the site was severely hampered because of muddy conditions; in fact, travel was virtually impossible except for a light, wide-track, D-4 Caterpillar bulldozer that generally left the road and went through the woods to avoid getting stuck in the road. The shear strength of the surface material was very low. All of the drilling equipment and the vibrator trafler used in the vibroseismic survey had to be winched to the site with the bulldozer. Each of the vehicles sank to the axles as soon as it left the pavement and had to be dragged to each location on site.

\section{Test Methods and Computations}

\section{Refraction seismic tests}

8. A conventional refraction seismic survey was conducted to determine the compression-wave velocities of the subsurface materials and depths to refracting interfaces. A portable selsmograph unit was used for refraction seismic survey and consisted of 12 geophones spaced at 
25-ft $(7.6 \mathrm{~m})$ intervals along each $300-\mathrm{ft}(91.4 \mathrm{~m})$ seismic transverse. The seismograph was equipped with a camera that provided a permanent record on film. Detonation of explosives provided the energy source.

9. Information obtained from surface refraction seismic tests consists basically of the time required for a compression wave to travel from a seismic source (explosives) to the points of measurement (geophones). Data are plotted in graphic form as travel time from the seismic source to each geophone versus the respective distances of the geophones from the source. The inverse slope of the lines drawn to connect the plotted points indicates the veloctiy of the compression wave through each subsurface medium encountered. A change in the slope of the line shows that the wave has passed through an interface between two subsurfaces layers having different velocities, and the second inverse slope of the line indicates the velocity of the second material encountered. The depth at which the first interface occurs below the surface can be calculated by the use of the following equation:

$$
D_{1}=\frac{x_{1}}{2} \sqrt{\frac{v_{c 2}-v_{c 1}}{v_{c 2}+v_{c 1}}}
$$

where

$$
\begin{aligned}
\mathrm{D}_{1}= & \text { depth from surface to first interface, } \mathrm{L} \\
\mathrm{x}_{1}= & \text { distance from seismic source to point at which first change in } \\
& \text { slope occurs, } \mathrm{L} \\
\mathrm{v}_{\mathrm{cl}}= & \text { compression-wave velocity in first layer, } \mathrm{LT}^{-1} \\
\mathrm{v}_{\mathrm{c} 2}= & \text { compression-wave velocity in second layer, } \mathrm{LT}^{-1}
\end{aligned}
$$

10. It should be noted that, in most cases, data from the forward and reverse profiles along a seismic line indicate different velocities for a particular soll layer. This difference in velocities is caused by a dip of the soil layer, and the velocities determined are apparent. However, the true velocity of the soll layer can be determined using the following equation:

$$
v_{t}=\frac{2 v_{u} v_{d}}{v_{u}+v_{d}}
$$


where

$v_{t}=$ true velocity of a soil layer, $\mathrm{LT}^{-1}$

$v_{u}=$ apparent velocity of a soil layer along the up-dip profile, $\mathrm{LT}^{-1}$

$\mathrm{v}_{\mathrm{d}}=$ apparent velocity of a soil layer along the down-dip profile, $\mathrm{LT}^{-1}$

Vibratory tests

11. The vibratory investigation was conducted utilizing a hydraulicpowered counterrotating eccentric weight vibrator as a wave source. The vibrator and associated instrumentation are described in detail in WES Miscellaneous Paper (MP) No. 4-577, "A Procedure for Determining Elastic Moduli of Soils by Field Vibratory Techniques," dated June 1963, and a supplementary report, MP No. 4-691, "Determination of Sol1 Shear Modul1 at Depth by In-Situ Vibratory Techniques," dated December 1964.

12. Data obtained from the vibration tests consist basically of determining the length of surface (Rayleigh) waves generated by vibrators at controlled frequecies. From this the wave velocity can be computed as follows:

$$
\mathrm{v}=\lambda \mathbf{f}
$$

where

$$
\begin{aligned}
& v=\text { wave velocity, } \mathrm{LT}^{-1} \\
& \lambda=\text { wavelength, } \mathrm{L} \\
& \mathrm{f}=\text { frequency of the vibrator, cycles } \mathrm{T}^{-1}
\end{aligned}
$$

Computation of elastic moduli

\section{and Poisson's ratios}

13. Wave velocity is dependent upon the ratio of the elasticity of the medium to its mass density $\rho$ and the wave type. The relation of shear modulus $G$ and shear-wave velocity $v_{S}$ is as follows:

$$
G=v_{s}^{2} \rho
$$

where

$$
\begin{aligned}
& \mathrm{G}=\text { shear modulus of soil, } \mathrm{FL}^{-2} \\
& \mathrm{v}_{S}=\text { shear-wave velocity, } \mathrm{LT}^{-1} \\
& \rho=\text { mass density of soil, } \mathrm{\gamma} / \mathrm{g}, \mathrm{GL}^{-4} \mathrm{~T}^{2} \\
& \gamma=\text { wet unit weight of soil, } \mathrm{FL}^{-3} \\
& g=\text { acceleration of gravity, } \mathrm{LT}^{-2} \\
& 5
\end{aligned}
$$


Shear-wave velocity and surface-wave velocity are related by Poisson's ratio. For Poisson's ratios ranging between 0.2 and 0.5 , the theoretical difference in velocities is less than nine percent for a homogeneous isotropic half space. Therefore, for practical purposes, shear waves can be considered to have the same velocity as surface waves. Thus, shear-wave velocities can be determined by the vibratory tests described, and shear moduli can be calculated by the use of equation 4 .

14. With the assumption that compression-wave velocity $v_{c}$ and shear-wave velocity $v_{s}$ were determined for comparable materials, Poisson's ratio can be calculated from the ratio of velocities $v_{r}$ :

$$
\mathrm{v}_{\mathrm{r}}=\frac{\mathrm{v}_{\mathrm{c}}}{\mathrm{v}_{\mathrm{s}}}
$$

Poisson's ratio $\nu$ is then:

$$
v=\frac{v_{r}^{2}-2}{2\left(v_{r}^{2}-1\right)}
$$

15. The compression modulus E (Young's modulus) can be determined by :

$$
E=2(1+v) G
$$

Based on WES experience, it appears that variations in $E$ and $G$ correlate best with conventional exploration methods when it is assumed that the computed values of E and $G$ are applicable at a depth of onehalf the length of the surface wave. Therefore, the computed values of $E$ and $G$ are considered to be the elastic modult at such a depth. For estimating properties of foundations under surcharge loads of the proposed construction, it is suggested that shear modulus and Poisson's ratio be selected as those determined from the depth at which the overburden pressure is equal to the static surcharge pressure of the proposed structure.*

* Department of the Army, EM 110-345-310, "Engineering and Design, Foundations Subject to Vibratory Loads," 19 May 1967, Washington, D. C. 


\section{PART III: TESTS CONDUCTED AND ANALYSIS AND DISCUSSION OF RESULTS}

\section{Refraction Seismic Tests}

16. Ten refraction selsmic traverses were run along the longitudinal axis of the proposed HIRT site. The locations of these traverses are shown in plate 4 and the time versus distance plots for the five traverses are shown in plates 5 through 9. There were no irregularities noted in the seismic data.

17. The time versus distance plots were used to construct subsurface profiles for seismic data. The subsurface profiles is shown in plate 4 in traverses $S-1$ through $S-10$. The profile includes the entire 1800-ft (549 m) site proposed for the HIRT facility. Data from a boring $\log$ located near the site (plate 1) and shown displayed in plate 10 ind1cate limestone at a depth of about $60 \mathrm{ft}(18 \mathrm{~m})$. Data from the seismic profile indicated two velocity zones above the limestone. The nearsurface materials exhibited a compression-wave velocity range of 2170 to $2500 \mathrm{fps}(660$ to $760 \mathrm{~m} / \mathrm{s}$ ) to depths varying from 2.7 to $10.7 \mathrm{ft}(0.8$ to $3.3 \mathrm{~m}$ ) below the ground surface. The second zone had a velocity range of 2950 to $5130 \mathrm{fps}(900$ to $1560 \mathrm{~m} / \mathrm{s}$ ) that extended to competent limestone at depths that varied from 48 to $92 \mathrm{ft}$ (15 to $28 \mathrm{~m}$ ) below the surface. Compression-wave velocities in the limestone varied from 14,300 to 21,000 fps $(4360$ to $6400 \mathrm{~m} / \mathrm{s})$. These data are also shown tabulated in detail in table 1 .

\section{Vibration Tests}

18. One vibration traverse was conducted at the proposed site of the HIRT facility about $3200 \mathrm{ft}(975 \mathrm{~m})$ north of 1 st street. The traverse was positioned at this location because the major components of the facility will be located in this area. The location of the traverse is shown in plate 4. Only one traverse was conducted because of the adverse site and weather conditions, mechanical difficulty with the vibrator, and rabbits eating the instrumentation cables. 
19. A plot of the shear-wave velocities versus depth is shown in plate 10. Shear-wave velocities near the surface were about $700 \mathrm{fps}$ $(215 \mathrm{~m} / \mathrm{s})$. The velocity increased uniformly with depth to about $1000 \mathrm{fps}$ $(305 \mathrm{~m} / \mathrm{s})$ at a depth of about $40.0 \mathrm{ft}(12.2 \mathrm{~m})$. Greater depths of penetration were not possible because the vibration signals were dampened very rapidly by the soft surface materials. These data are shown in table 1.

20. The seismic and vibratory data obtained at the site were utilized to compute Poisson's ratios, shear modull G, and compression moduli $E$. These data are shown tabulated in table 1 . A plot of $G$ and $E$ versus depth is shown in plate 11.

21. The moduli versus depth plot, plate 11 , Indicates a shear modulus of about $10,000 \mathrm{ps} 1\left(705 \mathrm{~kg} / \mathrm{cm}^{2}\right)$ at the surface increasing uniformly to about $20,000 \mathrm{ps} 1\left(1410 \mathrm{~kg} / \mathrm{cm}^{2}\right)$ at a depth of $40.0 \mathrm{ft}(12.2 \mathrm{~m})$. Compression moduli were approximately three times the shear modulf for corresponding depths. Polsson's ratios were computed for each modulus and ranged from 0.45 to 0.47 . Poisson's ratios and shear and compression modulf are shown tabulated in table 1 . 


\section{PART IV: CONCLUSIONS}

22. Three subsurface layers were determined from the seismlc tests conducted at the site. The near-surface materlal compression-wave velocities varled from 2170 to 2500 fps $(660$ to $760 \mathrm{~m} / \mathrm{s}$ ) and ranged in depth from 2.7 to $10.7 \mathrm{ft}(0.8$ to $3.3 \mathrm{~m})$. The second layer indicated a velocity range from 2950 to $5130 \mathrm{fps}(900$ to $1560 \mathrm{~m} / \mathrm{s})$ and varled in depth from 48 to $92 \mathrm{ft}$ ( 15 to $28 \mathrm{~m}$ ). Limestone bedrock was encountered below these depths with velocities ranging from 14,300 to $21,000 \mathrm{fps}$ (4360 to $6400 \mathrm{~m} / \mathrm{s}$ ).

23. The vibratory data indicated shear-wave velocities to vary from 700 to $1000 \mathrm{fps}(215$ to $305 \mathrm{~m} / \mathrm{s}$ ) at a depth of about $40.0 \mathrm{ft}(12.2 \mathrm{~m})$. Shear moduli ranged from about $10,000 \mathrm{psi}\left(705 \mathrm{~kg} / \mathrm{cm}^{2}\right.$ ) near the surface to about $20,000 \mathrm{psi}\left(1410 \mathrm{~kg} / \mathrm{cm}^{2}\right)$ at a depth of about $40.0 \mathrm{ft}(12.2 \mathrm{~m})$. Compression moduli were about three times the shear moduli for corresponding depths. Polsson's ratios varled from 0.45 to 0.47 . 
Table 1

Results of Vibroseismic Site Invest1gations

\begin{tabular}{|c|c|c|c|c|c|c|c|c|c|c|c|c|}
\hline \multirow[b]{2}{*}{$\begin{array}{l}\text { Wet Unit } \\
\text { We1ght } \\
\text { 1b/cu ft } \\
\end{array}$} & \multicolumn{4}{|c|}{ Selsm1c Test } & \multicolumn{5}{|c|}{ V1bration Test } & \multirow[b]{2}{*}{$\begin{array}{l}\text { Polsson's } \\
\text { Rat1o } \\
\end{array}$} & \\
\hline & $\begin{array}{r}\text { Tra- } \\
\text { verse } \\
\text { No. } \\
\end{array}$ & $\begin{array}{l}\text { Apparent } \\
\text { Velocity } \\
\mathrm{V}_{c^{\prime}, \text { fps }} \\
\end{array}$ & $\begin{array}{c}\text { True } \\
\text { Velocity } \\
\mathrm{v}_{c}, \mathrm{fps} \\
\end{array}$ & $\begin{array}{c}\text { Depth } \\
\mathrm{ft}\end{array}$ & $\begin{array}{l}\text { Tra- } \\
\text { verse } \\
\text { No. } \\
\end{array}$ & $\begin{array}{l}\text { Frequency } \\
\mathrm{f}, \mathrm{Hz} \\
\end{array}$ & $\begin{array}{l}\text { Wave- } \\
\text { length } \\
\lambda, \mathrm{ft} \\
\end{array}$ & $\begin{array}{c}\text { Wave } \\
\text { Velocity } \\
v_{8}, \text { fps } \\
\end{array}$ & $\begin{array}{c}\text { Depth } \\
\mathrm{ft} \\
\end{array}$ & & $\begin{array}{l}\text { Modulus } \\
\text { Shear } \\
\mathrm{G} \\
\end{array}$ & $\begin{array}{c}\frac{10^{3}}{\text { Compression }} \\
\mathrm{E}\end{array}$ \\
\hline 108 & S-1 & 2,270 & 2,270 & $00.0-05.5$ & & & & & & & & \\
\hline \multirow[t]{2}{*}{110} & & 3,850 & 3,640 & $05.5-61.0$ & & & & & & & & \\
\hline & & 14,300 & 14,300 & $61+$ & & & & & $\cdot$ & $\ldots$ & & - \\
\hline 108 & $s-2$ & 2,270 & & $00.0-05.7$ & & & & & & & & \\
\hline \multirow[t]{2}{*}{110} & & 3,450 & & $05.7-56.0$ & & & & & & & & \\
\hline & & 14,300 & & $56+$ & & & & & & & & \\
\hline 108 & $s-3$ & 2,080 & 2,170 & $00.0-02.7$ & $v-1$ & 62.5 & 11.2 & 700 & 5.6 & 0.47 & 11.5 & 34.0 \\
\hline \multirow[t]{13}{*}{110} & & 3,040 & 2,950 & $02.7-48.0$ & & 30.0 & 24.8 & 740 & 12.4 & 0.47 & 13.1 & 38.5 \\
\hline & & 16,000 & 16,000 & $48+$ & & 25.0 & 33.2 & 833 & 16.6 & 0.46 & 16.5 & 48.2 \\
\hline & & & & & & 24.0 & 30.8 & 740 & 15.4 & 0.47 & 13.1 & 38.5 \\
\hline & & & & & & 22.2 & 34.2 & 760 & 17.1 & .0 .47 & 13.8 & 40.5 \\
\hline & & & & & & 21.3 & .44 .0 & .910 & .22 .0 & .0 .45 & 19.7 & 57.2 \\
\hline & & & & & & 20.0 & 41.6 & 832 & $\therefore 20.8$ & 0.46 & 16.5 & 48.2 \\
\hline & & & & & & 18.9 & 40.6 & 770 & 20.3 & 0.47 & 14.1 & 41.5 \\
\hline & & & & & & 18.0 & 42.8 & 770 & 21.4 & 0.47 & 14.1 & 41.5 \\
\hline & & & & & & 16.7 & 60.0 & 1000 & 30.0 & 0.45 & 23.8 & 69.2 \\
\hline & & & & & & 13.4 & 74.6 & 1000 & 37.3 & 0.45 & 23.8 & 69.2 \\
\hline & & & & & & 13.0 & 70.0 & 910 & 35.0 & 0.45 & 19.7 & 57.2 \\
\hline & & & & & & 12.5 & 72.0 & 900 & .36 .0 & 0.45 & 19.3 & 56.0 \\
\hline & & & & & & .11 .1 & $\therefore 82.0:$ & $: 910$ & $\therefore 41.0$ & .0 .45 & 19.7 . & .57 .2 \\
\hline 108 & $5-4:$ & : 2,270 & & $00.0-04.2=$ & & & & & & & & \\
\hline \multirow[t]{2}{*}{110} & & 2,860 & & $04.2-56.0$ & & . & & & & & & \\
\hline & & 16,000 & & $56+$ & & & & & & & & \\
\hline 108 & $s-5$ & 2,500 & 2,500 & $00.0-05.5$ & & & & : & & . & & \\
\hline \multirow[t]{2}{*}{110} & & 3,700 & 3,770 & $05.5-65.0$ & & & & & & & & \\
\hline & & 22,200 & 20,000 & $65+$ & & & & & & & & \\
\hline 108 & $s-6$ & 3,850 & & $00.0-61.0$ & & & & & & & & \\
\hline 110 & & 18,200 & & $61+$ & & & & & & & & \\
\hline 108 & $s-7$ & 2,780 & 2,380 & $00.0-05.2$ & & & & & & & & . \\
\hline 110 & & $\begin{array}{r}4,350 \\
14,300\end{array}$ & $\begin{array}{r}4,650 \\
14,300\end{array}$ & $\begin{array}{c}05.2-64.0 \\
64+\end{array}$ & & & & & & $\cdot$ & & \\
\hline \multirow[t]{3}{*}{108} & $\mathrm{~S}-8$ & 2,080 & & $00.0-08.0$ & & & & $\cdot$ & & & & \\
\hline & & $: 5,000::$ & & $08.0-70.0$ & & & & & & $\cdot$ & & \\
\hline & & 14,300 & $\ldots$ & $70+$ & $\cdot$ & & & & & & & \\
\hline 108 & $s-9$ & 2,270 & 2,270 & $00.0-09.2$ & & & & & & & & \\
\hline \multirow[t]{2}{*}{110} & & 5,270 & 5,130 & $09.2-86.0$ & & & & & & & & \\
\hline & & 22,200 & 21,000 & $86+$ & & & & & & & & \\
\hline 108 & s-10 & 2,270 & & $00.0-10.7$ & & . & & & & & & \\
\hline \multirow[t]{2}{*}{110} & & 5,000 & & $10.7-92.0$ & & & & & & & & \\
\hline & & 20,000 & & $92+$ & & & & & & & & \\
\hline
\end{tabular}




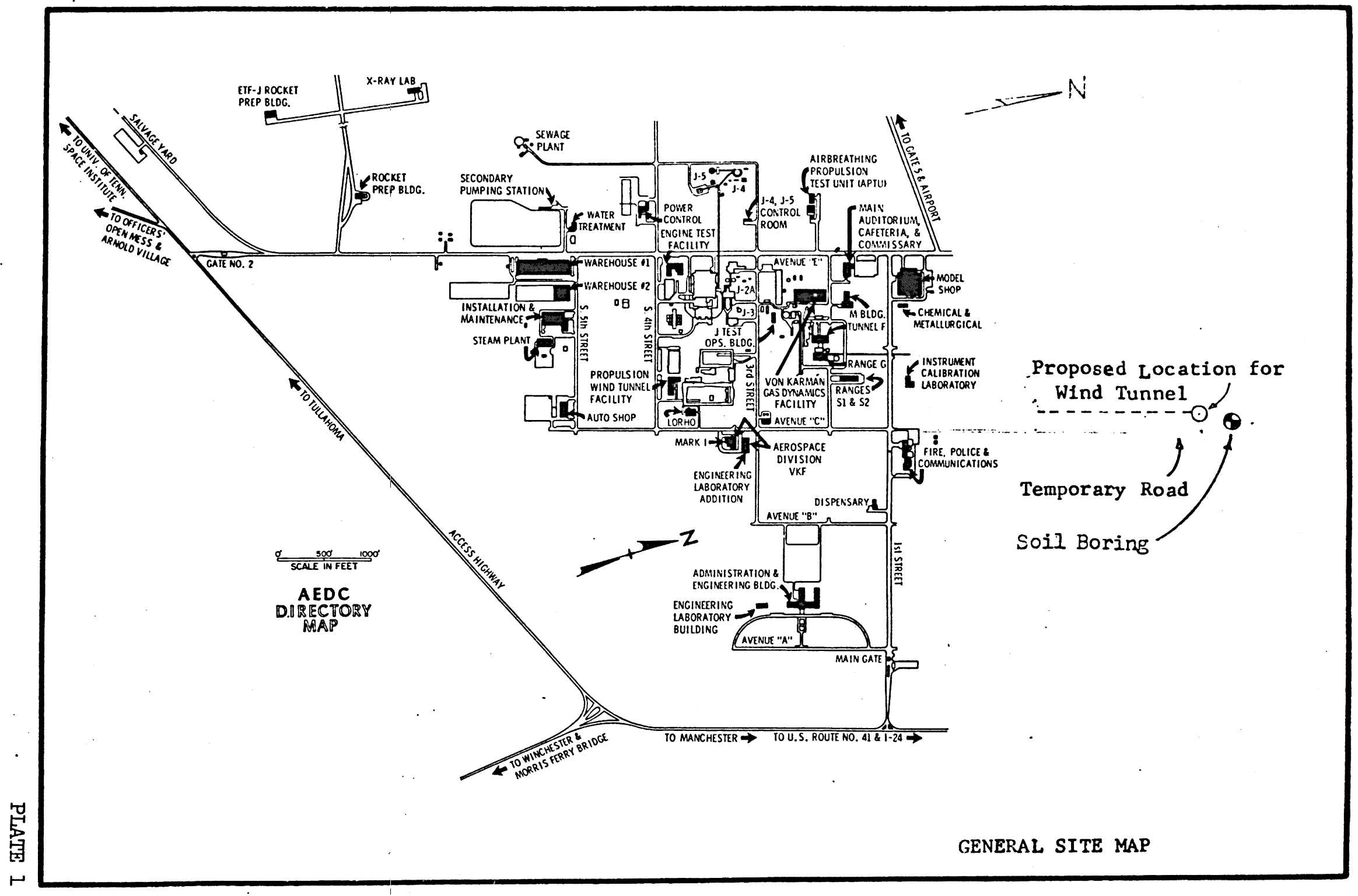




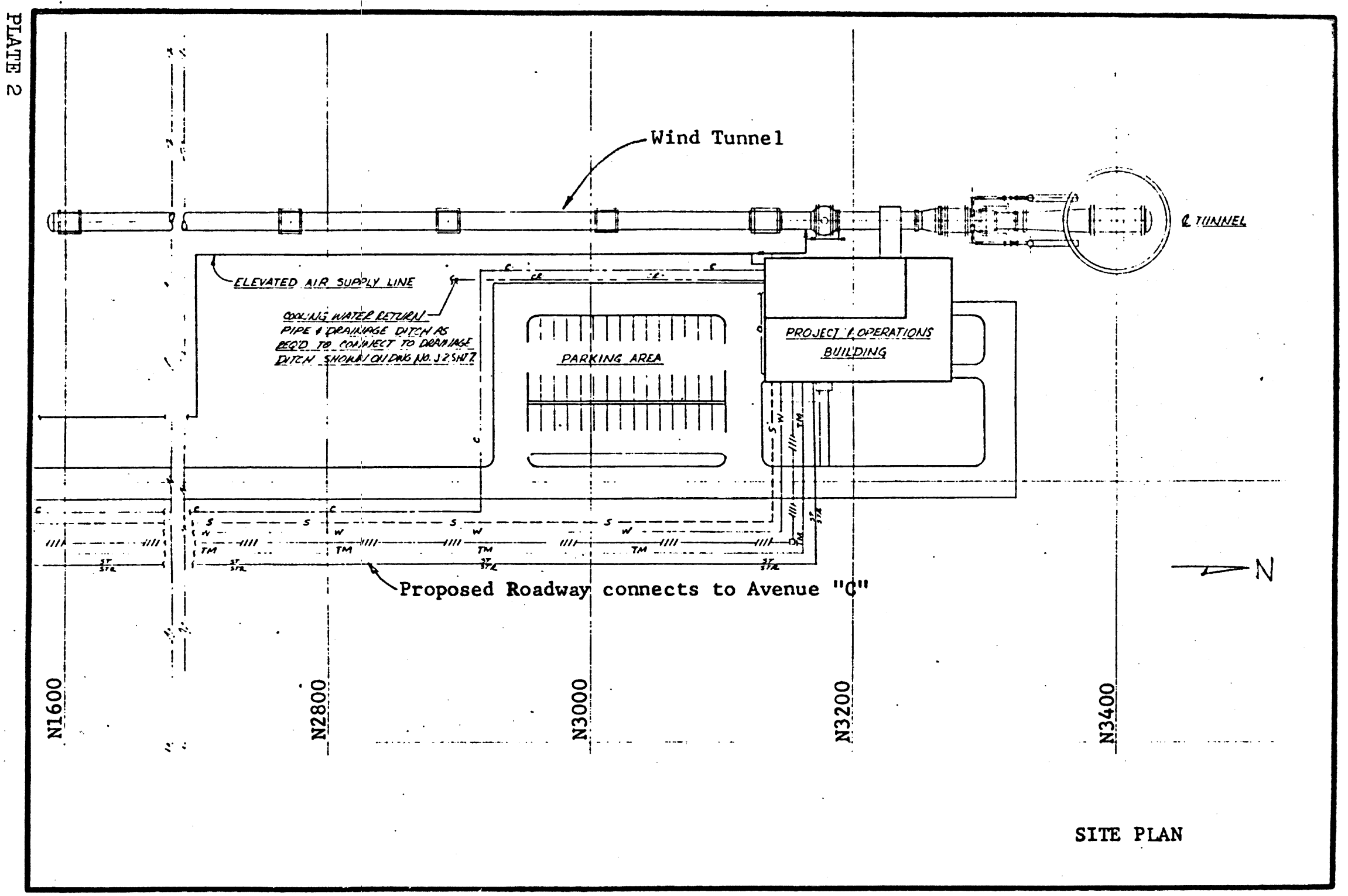




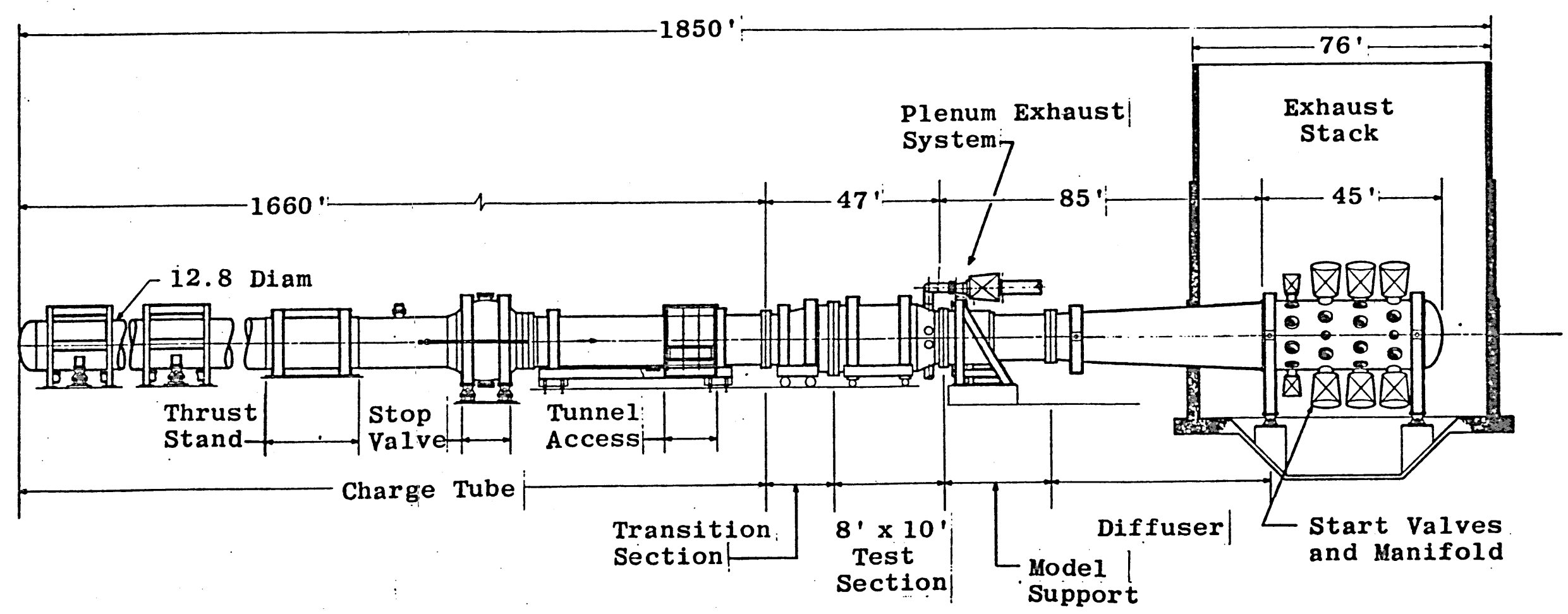

GENERAL CONFIGURATION OF AEDC HIGH REYNOLDS NUMBER TUNNEL (HIRT) 


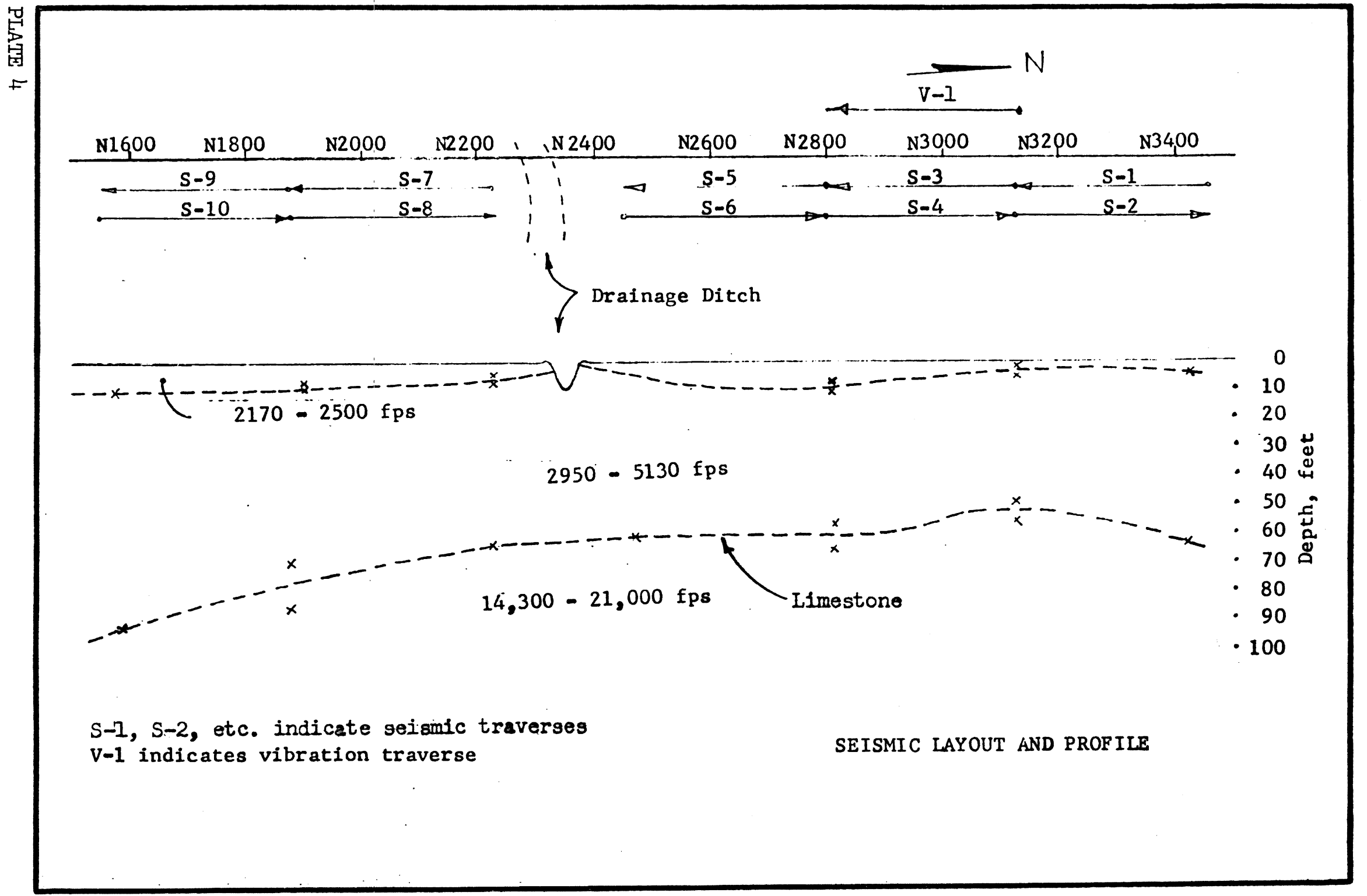




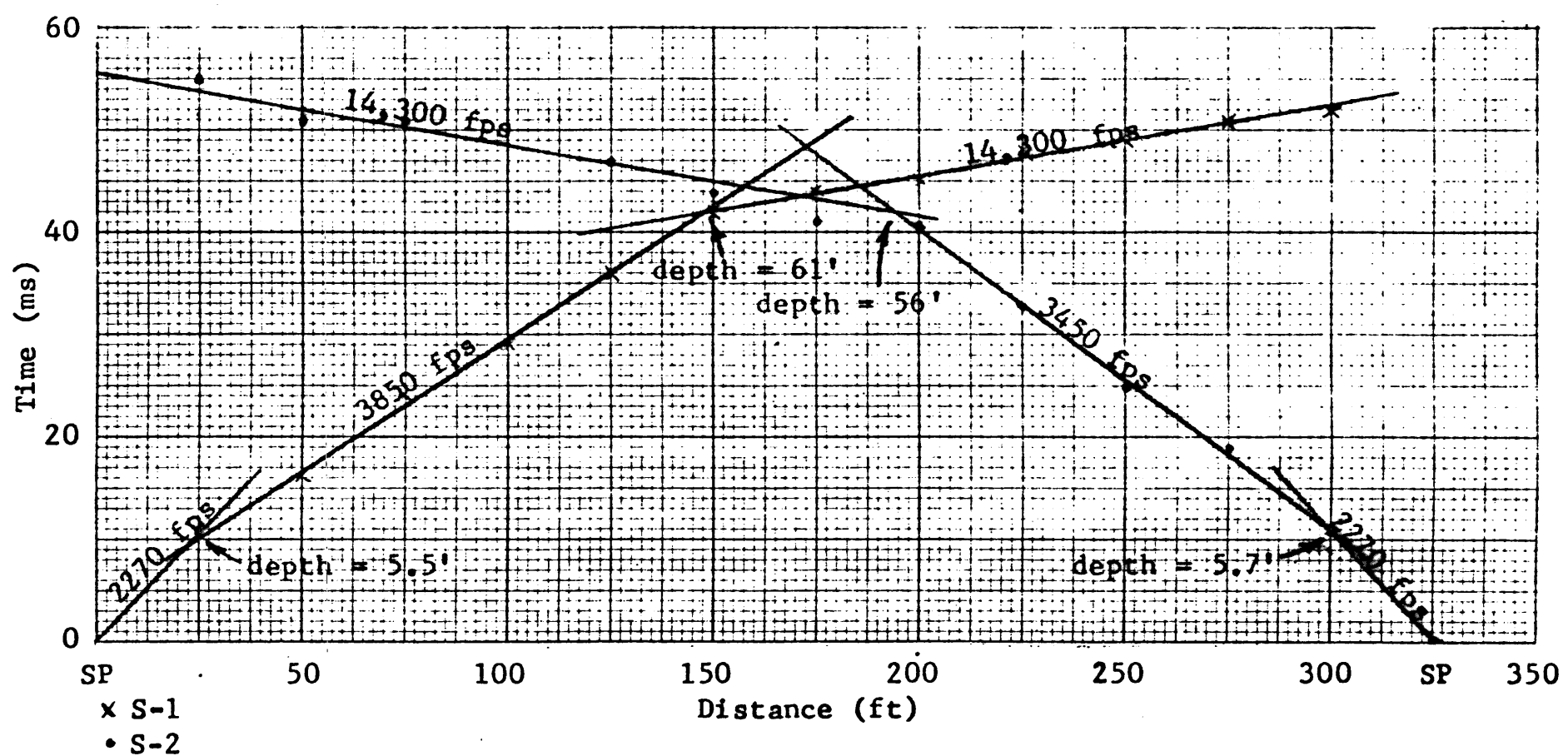

True Velocity, fps

$D_{1}=2270$

$\mathrm{D}_{2}=3640$

$\mathrm{D}_{3}=\mathrm{I}_{4}, 30 \mathrm{C}$ 


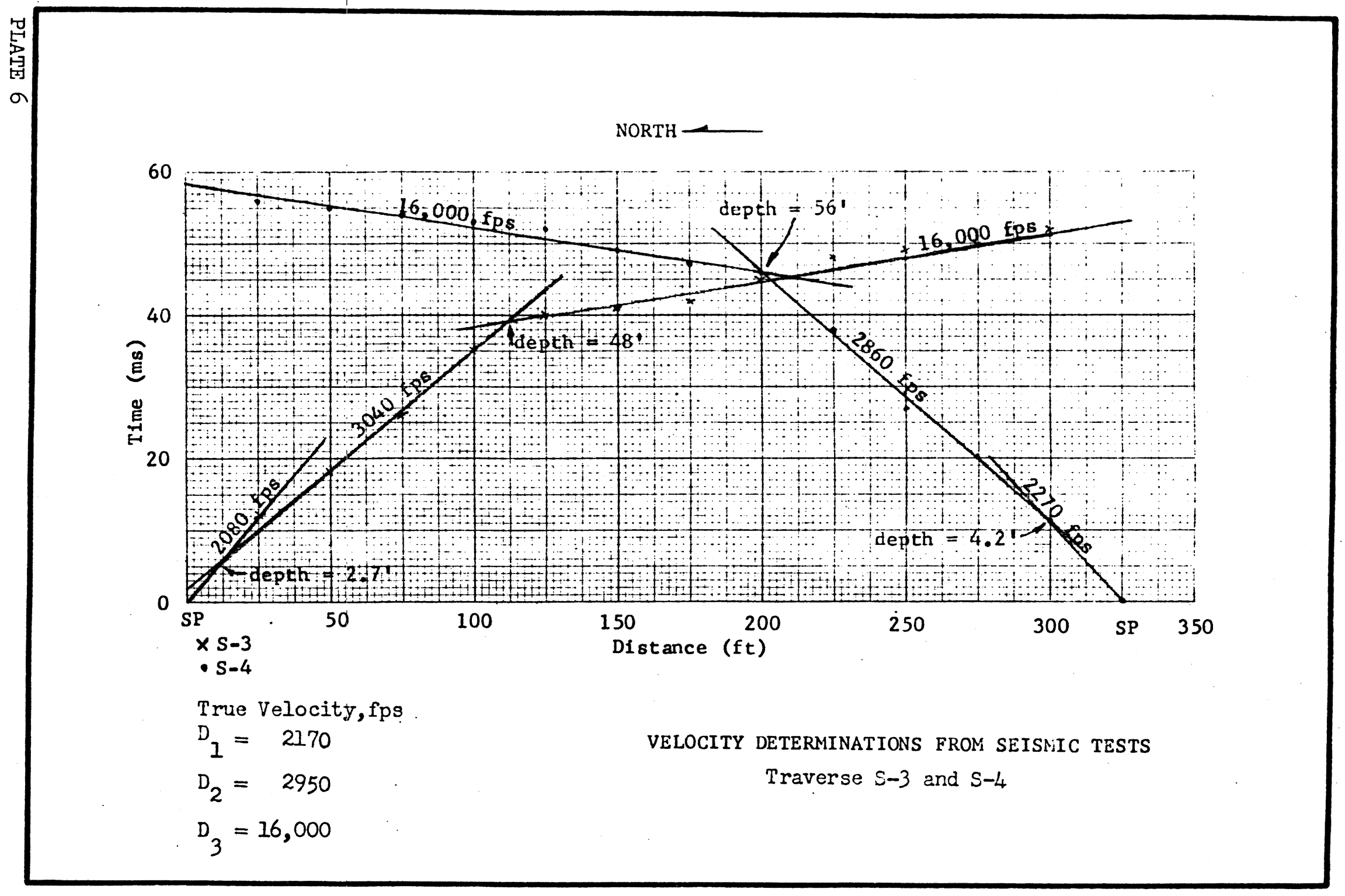


NORTH

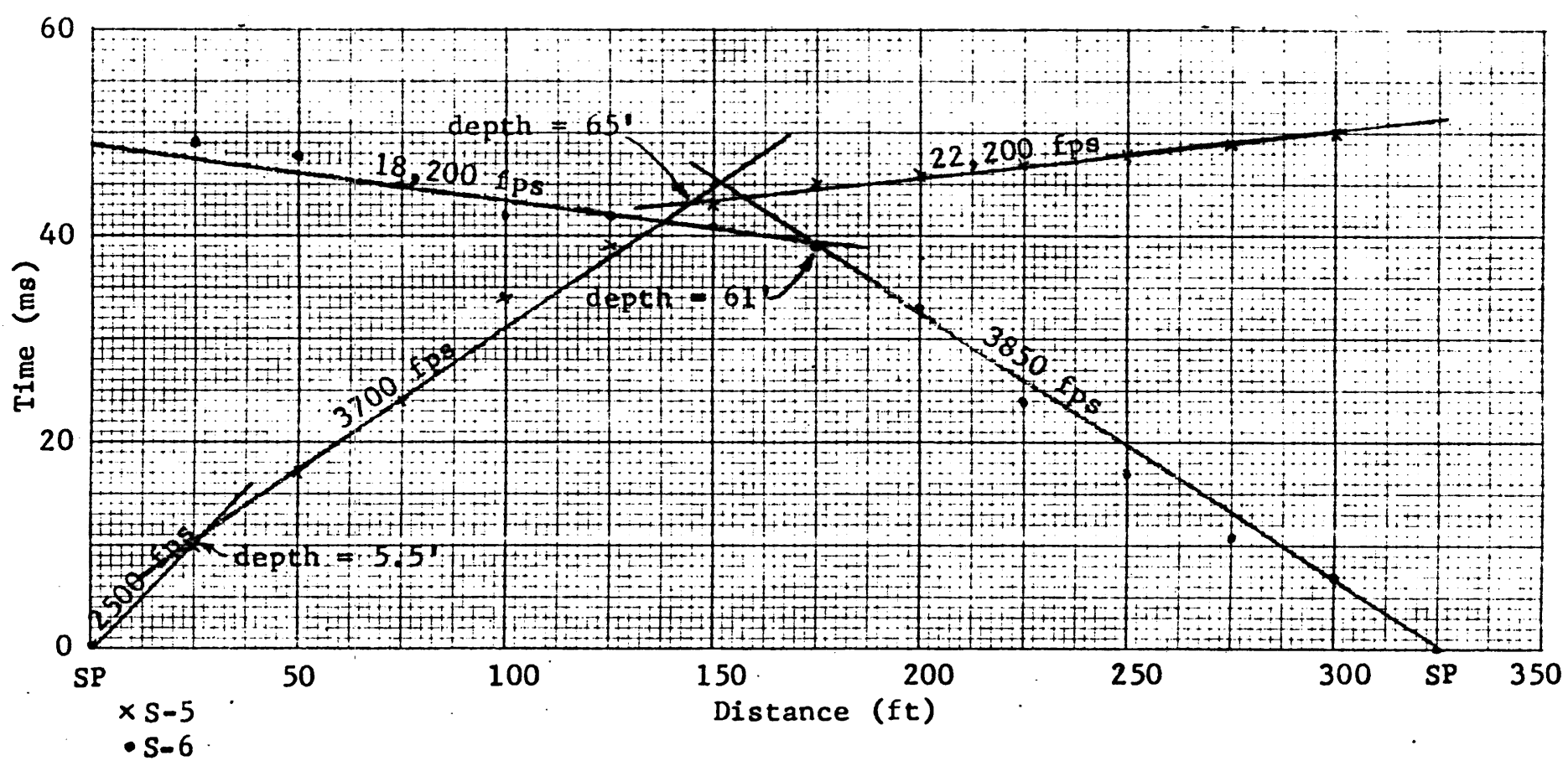

True Velocity,fps

$D_{1}=2500$

VELOCITY DETERMINATIONS FROM SEISMIC TESTS

$\mathrm{D}_{2}=3770$

Traverse $s-5$ and $s-6$ 


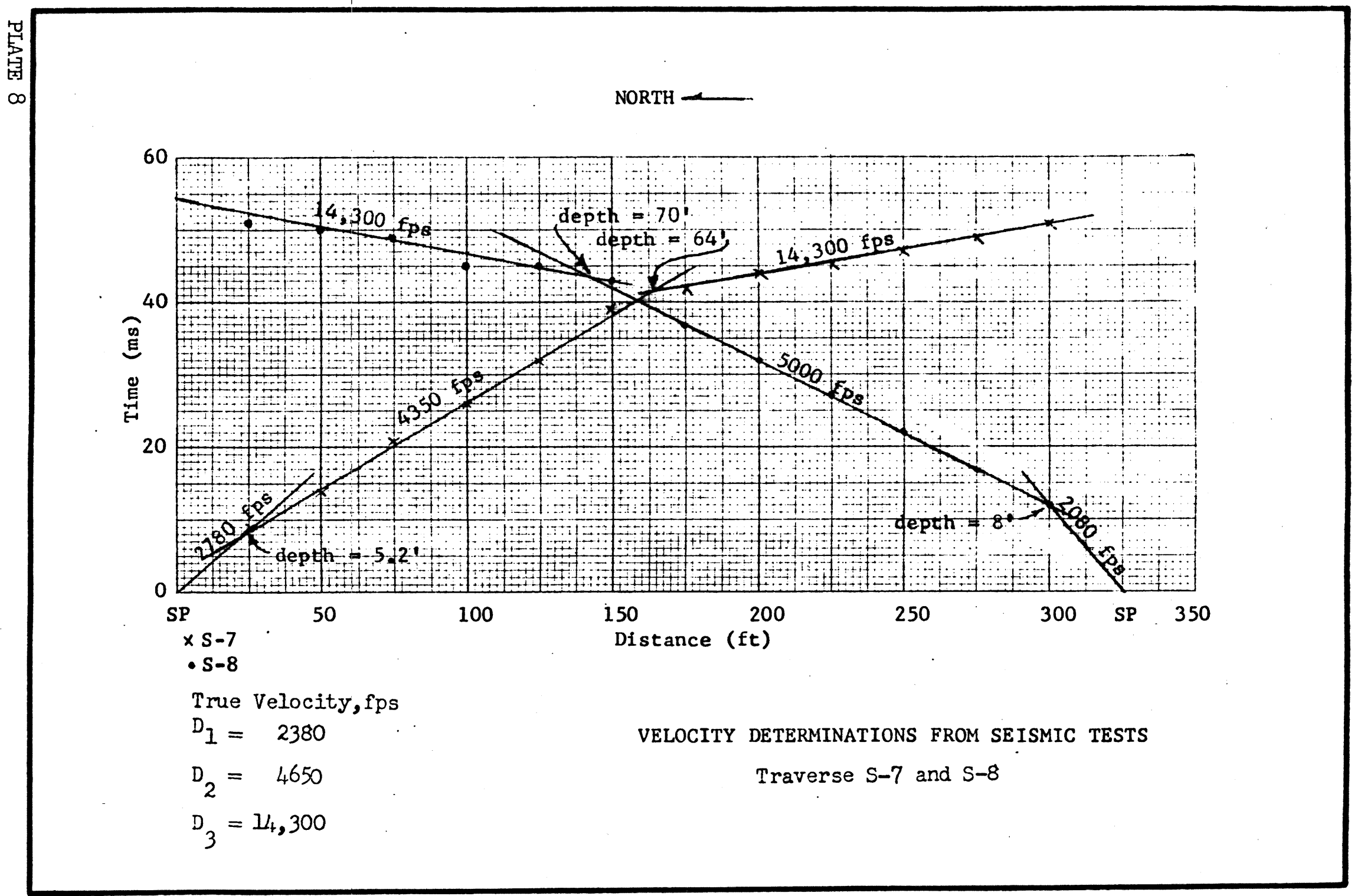




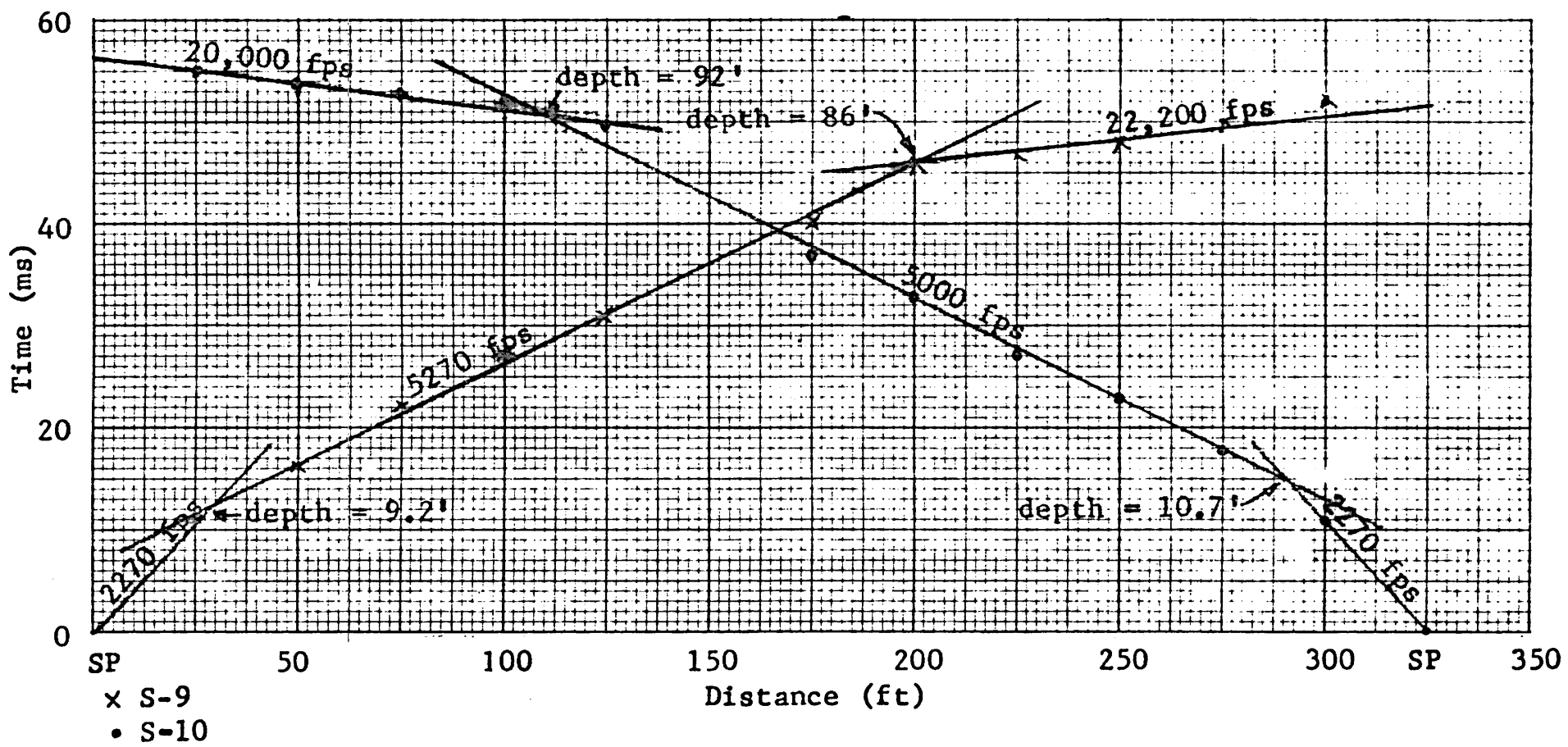

True Velocity,fps

$D_{I}=2270$

VELOCITY DETERMINATIONS FROM SEISMIC TESTS

$\mathrm{D}_{2}=5130$

Traverse $S-9$ and $S-10$

$D_{3}=21,000$ 
SHEAR WAVE| VELOCITY, fps

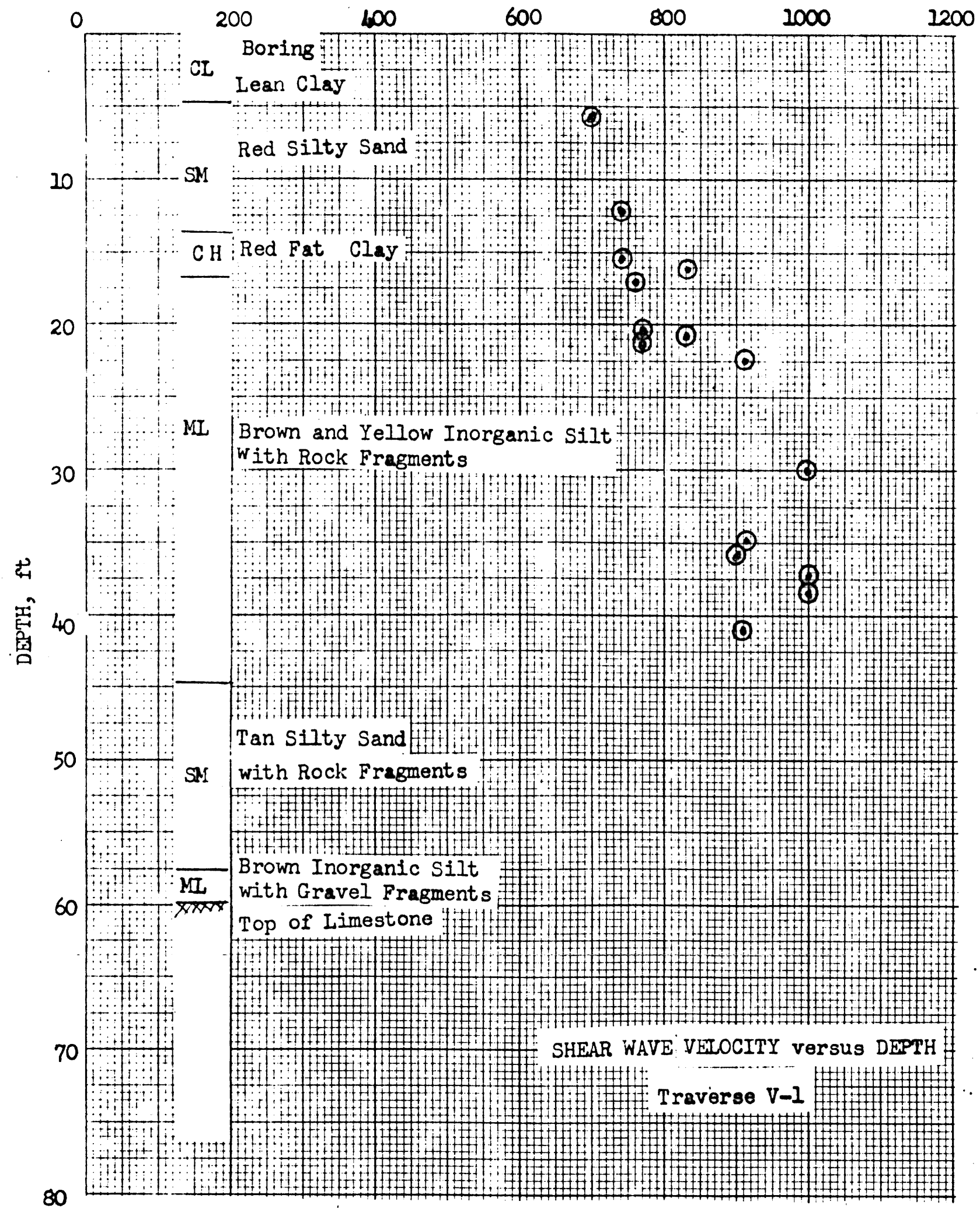


Unclassified

Security Classification

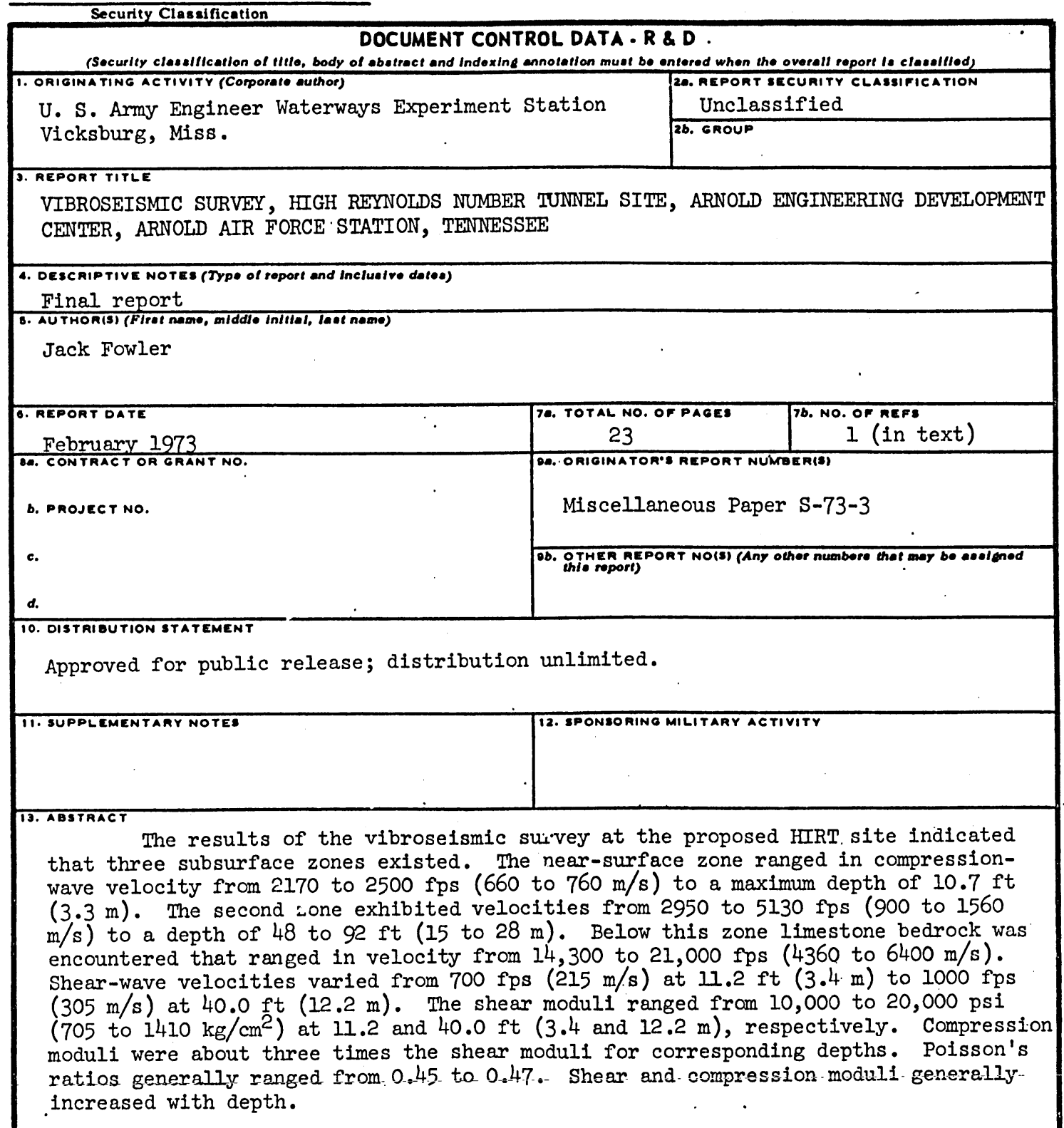




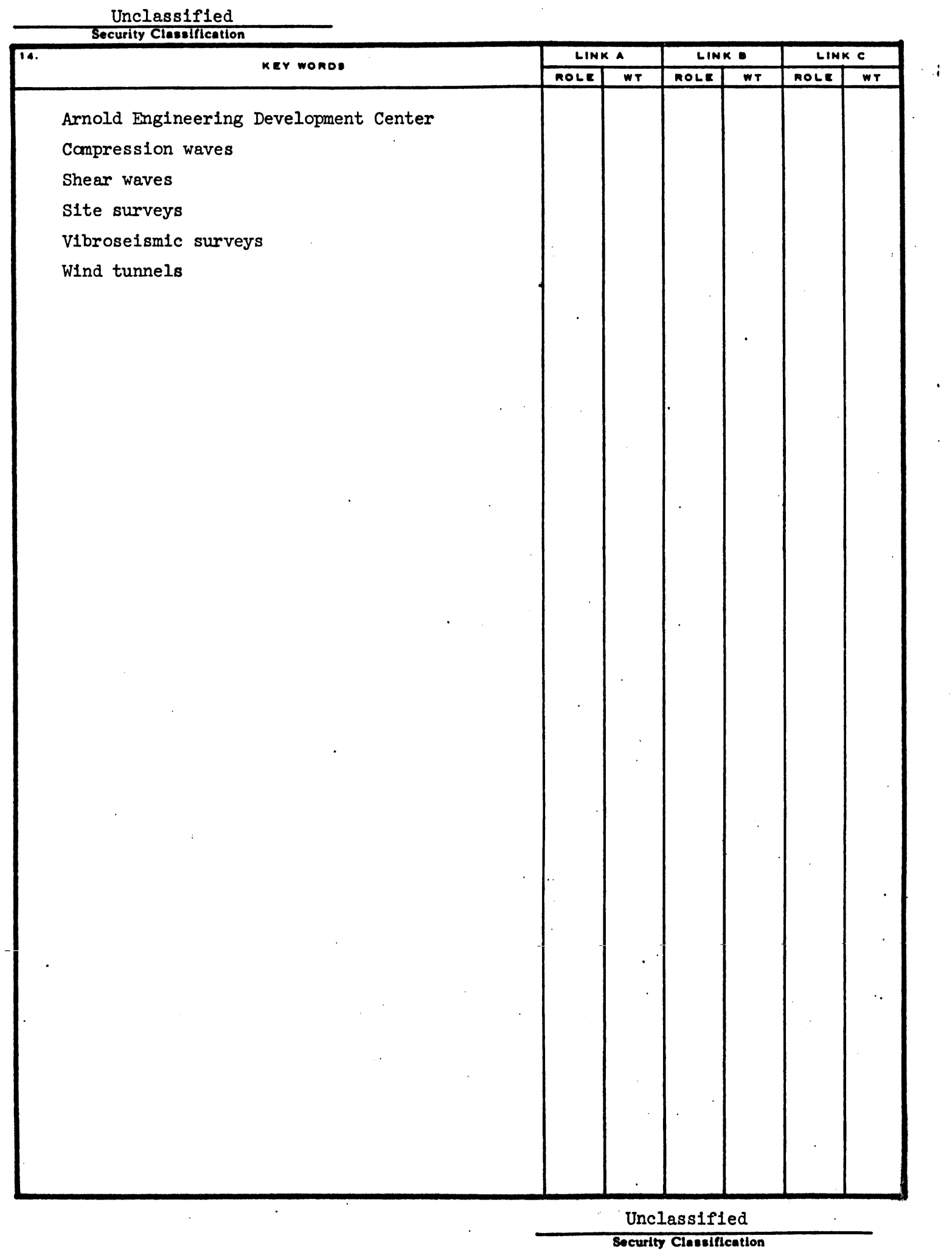

